\title{
Effects of Cyanocobalamin on Immunity in Patients with Pernicious Anemia
}

\author{
Mehmet Ali Erkurt ${ }^{\mathrm{a}} \quad$ Ismet Aydogdu ${ }^{\mathrm{a}}$ Mustafa Dikilitaş ${ }^{\mathrm{b}} \quad$ Irfan Kuku $^{\mathrm{a}}$ \\ Emin Kaya $^{\mathrm{a}}$ Nihayet Bayraktar ${ }^{c}$ Onur Ozhan ${ }^{\mathrm{b}}$ Ibrahim Ozkan ${ }^{\mathrm{a}}$ \\ Ahmet Sönmez ${ }^{\text {a }}$
}

Departments of ${ }^{a}$ Hematology, ${ }^{b}$ Internal Medicine and ${ }^{\mathrm{c} B i o c h e m i s t r y, ~ F a c u l t y ~ o f ~ M e d i c i n e, ~ I n o n u ~ U n i v e r s i t y, ~}$ Malatya, Turkey

\author{
Key Words \\ Pernicious anemia $\cdot$ Vitamin $B_{12} \cdot$ Immunity $\cdot$ Natural killer \\ cells $\cdot \mathrm{CD} 4 / \mathrm{CD} 8$ ratio
}

munomodulatory effects on cellular immunity, and abnormalities in the immune system in pernicious anemia are restored by vitamin $B_{12}$ replacement therapy.

\section{Copyright $\odot 2008$ S. Karger AG, Basel}

\section{Introduction}

The role of vitamin $B_{12}$ in human immunity is still obscure. There are few studies reporting changes observed in immune parameters after vitamin $\mathrm{B}_{12}$ administration in patients with pernicious anemia [1-5]. However, some of these studies were case reports or inadequately designed clinical trials.

The most important function of vitamin $\mathrm{B}_{12}$ is in DNA synthesis where it is necessary for cell replication. In this process vitamin $B_{12}$ acts with folic acid. It is believed that vitamin $B_{12}$, which has a role in cell division, also acts as a modulator of human immunity; it facilitates the production of Tlymphocytes recruited in cellular immunity, restores abnormally increased CD4/CD8 ratio and maintains the count of lymphocyte subgroups in the normal range [6]. An in vitro experimental study demonstrated that vitamin $\mathrm{B}_{12}$ was implicated in concanavalin Adependent $T$ cell production and pokeweed mitogendependent immunoglobulin synthesis in B cells [7]. In animal models, immune defense against viruses and

\section{KARGER}

Fax +41 613061234

E-Mail karger@karger.ch

www.karger.com (c) 2008 S. Karger AG, Basel

$1011-7571 / 08 / 0172-0131 \$ 24.50 / 0$

Accessible online at:

www.karger.com/mpp
Mehmet Ali Erkurt

Department of Hematology, School of Medicine

Turgut Özal Medical Center, Inonu University

TR-44069 Malatya (Turkey)

Tel. +90 422341 0660, ext. 4224, Fax +90 422341 0728, E-Mail maerkurt@inonu.edu.tr 
Table 1. Some blood parameters of patients before treatment

\begin{tabular}{lllllc}
\hline Parameters & Min. & Max. & Mean & SD & Normal range \\
\hline Hemoglobin, g/dl & 3.1 & 10.30 & 7.1 & 1.86 & $11.5-16$ \\
Hematocrit, \% & 8.6 & 30.50 & 20.6 & 5.89 & $34-45$ \\
Mean corpuscular volume, fl & 97 & 139.00 & 113.7 & 12.44 & $80-95$ \\
Platelet count, $\times 10^{3} / \mathrm{ml}$ & 6 & 528.00 & 142.9 & 104.62 & $150-450$ \\
Leukocyte count, $\times 10^{3} / \mu \mathrm{l}$ & 1.1 & 11.70 & 4.4 & 2.13 & $4-11$ \\
LDH, U/l & 530 & 13,429 & $4,960.9$ & $3,129.44$ & $200-350$ \\
Potassium, mmol/l & 3.6 & 4.90 & 4.2 & 0.27 & $3.5-5.5$ \\
Uric acid, $\mu \mathrm{mol} / \mathrm{l}$ & 130.8 & 547.4 & 326.5 & 95.7 & $154-422$ \\
Unconjugated bilirubin, $\mu \mathrm{mol} / \mathrm{l}$ & 0.4 & 16.7 & 5.2 & 2.3 & $0-10$ \\
Conjugated bilirubin, $\mu \mathrm{mol} / \mathrm{l}$ & 0.22 & 6.4 & 1.4 & 1.2 & $0-4$ \\
Vitamin $\mathrm{B}_{12}, \mathrm{pg} / \mathrm{ml}$ & 50 & 180 & 85.2 & 73.4 & $200-900$ \\
Folic acid, ng/ml & 0.92 & 22.3 & 6.7 & 5.07 & $2.7-16.1$ \\
\hline
\end{tabular}

bacteria was found to be depressed in vitamin $B_{12}$ deficiency [8].

In this study we evaluated the role of vitamin $B_{12}$ in patients with pernicious anemia. The measurements included the activity of subgroups of $\mathrm{T}$ and $\mathrm{B}$ lymphocytes and natural killer (NK) cells, levels of serum C3, C4 and immunoglobulins before and after vitamin $\mathrm{B}_{12}$ administration.

\section{Subjects and Methods}

This study was conducted prospectively in Turgut Özal Medical Center, Department of Hematology, between April and November 2002. Thirty patients (16 male and 14 female, age 17-75, average 55 years) with pernicious anemia were enrolled in the study. Diagnostic criteria of the patients are summarized in table 1. All patients showed low serum levels of vitamin $B_{12}$ (the average value and the normal range were 85 and $200-900 \mathrm{pg} / \mathrm{ml}$, respectively). Diagnosis was based on the medical history, macroovalocytosis in peripheral blood, megaloblastic changes in bone marrow, low serum levels of vitamin $B_{12}$, increased serum LDH and indirect bilirubin levels, and grade 4 atrophic gastritis in endoscopic biopsy.

In order to evaluate changes in leukocyte and lymphocyte numbers, absolute numbers and the ratio of the surface antigens of T and $\mathrm{B}$ lymphocyte subgroups, $\mathrm{CD} 4 / \mathrm{CD} 8$ ratio, NK cell activity, serum C3, C4, and immunoglobulin G, A, and M (IgG, IgA, IgM) levels were measured before treatment and compared with the values obtained during peak reticulocyte count.

Cyanocobalamin (Dodex) was administered $(1,000 \mu \mathrm{g} /$ day intramuscularly) until the reticulocyte crisis occurred and serum vitamin $B_{12}$ levels returned to the normal range.

\section{Surface Marker Analysis}

Peripheral blood was obtained in tubes containing EDTA K3. Ten microliters of monoclonal antibody solution was added to 100 $\mu \mathrm{l}$ of peripheral blood and incubated at room temperature for
$30 \mathrm{~min}$. The mononuclear cell fraction was collected by centrifugation on lymphocyte separation medium (Coulter Q-PREP, Epics Immunology Workstation, USA). Mononuclear cells were analyzed by flow cytometry (Beckman Coulter Epics Altra) before and after treatment. Surface marker analysis was performed within $2 \mathrm{~h}$ of blood collection. Commercial monoclonal antibodies used for immunophenotyping were as follows: $\mathrm{CD} 3 \mathrm{~T}$ cell FITC clone UCHT1, CD4 T cell FITC clone MT310, CD7 T cell FITC clone DK24, CD8 T cell FITC clone DK25, CD10 CALLA RPR clone SS2/36, CD16 FC gamma receptor III FITC clone DJ130C, CD19 B cell FITC clone HD37, CD20 B cell FITC clone B-Lyl, CD22 B cell FITC clone 4KB128, CD56 NK cell RPE cloneMOC-1 (DAKO Denmark).

\section{Complement and Immunoglobulin Analysis}

Serum C3, C4, IgA, IgM, and IgG were measured by the nephelometric method (Behring 100 Analyzer, Newark, N.J., USA), using the Dade Behring (Newark, N.J., USA) commercial kit.

\section{Statistical Analysis}

Statistical analysis was done by SPSS (Statistical Program for Social Sciences, version 10.0, Chicago, Ill., USA). Significance of differences was evaluated with paired $t$ test; $p<0.05$ was regarded as statistically significant.

\section{Results}

Mean leukocyte count before and after treatment was $4,432.3 \pm 2,131.7$ and $5,416.1 \pm 1,697.5 / \mathrm{mm}^{3}$, respectively. Increase in leukocyte count with treatment was statistically significant $(\mathrm{p}=0.009)$. Lymphocyte counts before and after treatment were 2,850.1 \pm 781.7 and 2,514 \pm $830 / \mathrm{mm}^{3}$, respectively, and the difference was statistically significant $(\mathrm{p}=0.008$; table 2 , fig. 1$)$. 
Table 2. Immune parameters before and after cyanocobalamin treatment

\begin{tabular}{|c|c|c|c|c|}
\hline \multirow[t]{2}{*}{ Parameters } & \multicolumn{2}{|l|}{ Treatment } & \multirow[t]{2}{*}{$\mathrm{p}$ value } & \multirow[t]{2}{*}{ Normal range } \\
\hline & before & after & & \\
\hline Leukocytes $/ \mathrm{mm}^{3}$ & $4,432 \pm 2,131$ & $5,416 \pm 1,697$ & 0.009 & $4,000-11,000$ \\
\hline Lymphocytes $/ \mathrm{mm}^{3}$ & $2,850 \pm 781$ & $2,514 \pm 830$ & 0.008 & $1,500-3,500$ \\
\hline $\mathrm{CD} 4, \%$ & $44.22 \pm 7.64$ & $44.33 \pm 7.65$ & NS & $26-58$ \\
\hline $\mathrm{CD} 4 / \mathrm{mm}^{3}$ & $1,048 \pm 337$ & $1,056 \pm 373$ & NS & $1,000-2,000$ \\
\hline CD8, \% & $26.69 \pm 10.23$ & $29.42 \pm 10.9$ & 0.002 & $20-42$ \\
\hline $\mathrm{CD} 8 / \mathrm{mm}^{3}$ & $606 \pm 239$ & $689 \pm 318$ & 0.035 & $240-1,000$ \\
\hline CD4/CD8 ratio & $2.00 \pm 1.05$ & $1.80 \pm 0.83$ & 0.06 & $1.5-2.0$ \\
\hline $\mathrm{CD} 3, \%$ & $69.06 \pm 11.71$ & $73.01 \pm 8.02$ & 0.042 & $57-81$ \\
\hline $\mathrm{CD} 3 / \mathrm{mm}^{3}$ & $1,573 \pm 512$ & $1,752 \pm 542$ & 0.015 & $1,200-2,500$ \\
\hline CD7, \% & $44.29 \pm 7.64$ & $46.85 \pm 12.94$ & NS & $34-69$ \\
\hline $\mathrm{CD} 7 / \mathrm{mm}^{3}$ & $1,002 \pm 353$ & $1,044 \pm 376$ & NS & $1,000-2,000$ \\
\hline CD10, \% & $7.60 \pm 7.76$ & $7.86 \pm 7.23$ & NS & $4-12$ \\
\hline $\mathrm{CD} 10 / \mathrm{mm}^{3}$ & $181 \pm 185$ & $190 \pm 222$ & NS & $100-300$ \\
\hline $\mathrm{CD} 16+\mathrm{CD} 56, \%$ & $17 \pm 7.28$ & $19 \pm 7.45$ & NS & $8-28$ \\
\hline $\mathrm{CD} 16+\mathrm{CD} 56 / \mathrm{mm}^{3}$ & $264 \pm 112$ & $287 \pm 126$ & NS & $212-318$ \\
\hline CD19, \% & $12.50 \pm 6.93$ & $18.76 \pm 6.98$ & 0.016 & $10-27$ \\
\hline $\mathrm{CD} 19 / \mathrm{mm}^{3}$ & $254 \pm 149$ & $348 \pm 146$ & 0.002 & $200-400$ \\
\hline CD20, \% & $18.50 \pm 6.95$ & $17.37 \pm 7.68$ & NS & $11-25$ \\
\hline $\mathrm{CD} 20 / \mathrm{mm}^{3}$ & $412 \pm 142$ & $355 \pm 144$ & 0.035 & $300-500$ \\
\hline $\mathrm{CD} 22, \%$ & $14.43 \pm 6.09$ & $12.98 \pm 6.39$ & NS & $10-20$ \\
\hline $\mathrm{CD} 22 / \mathrm{mm}^{3}$ & $322 \pm 134$ & $271 \pm 147$ & NS & $200-400$ \\
\hline $\mathrm{C} 3, \mathrm{~g} / \mathrm{l}$ & $0.75 \pm 0.21$ & $0.92 \pm 0.27$ & 0.001 & $0.8-1.5$ \\
\hline C4, g/l & $0.21 \pm 0.15$ & $0.21 \pm 0.14$ & NS & $0.15-0.35$ \\
\hline IgG, g/l & $10.07 \pm 2.77$ & $11.28 \pm 3.44$ & 0.04 & $7-15$ \\
\hline IgA, g/l & $2.41 \pm 1.63$ & $3.81 \pm 2.76$ & 0.01 & $0.8-4$ \\
\hline IgM, g/l & $0.93 \pm 0.45$ & $1.16 \pm 0.57$ & 0.03 & $0.4-2.6$ \\
\hline
\end{tabular}

NS $=$ Not significant.

\section{Effects of Cyanocobalamin Administration on}

\section{T Lymphocyte Subsets}

Mean absolute number and CD4 (\%) before and after treatment were $1,048.6 \pm 337.3 / \mathrm{mm}^{3}, 44.2 \pm 7.6(\%)$ and $1,056.4 \pm 373.4 / \mathrm{mm}^{3}, 44.3 \pm 7.6(\%)$, respectively. The difference was not statistically significant $(p=0.894)$. Mean absolute number and the CD8 (\%) before and after treatment were $606.95 \pm 239.26 / \mathrm{mm}^{3}, 26.6 \pm 10.2(\%)$ and $689.09 \pm 308.22 / \mathrm{mm}^{3}, 29.4 \pm 10.9(\%)$, respectively. The increases in the absolute number and CD8 (\%) were statistically significant $(\mathrm{p}=0.035$ and $\mathrm{p}=0.002)$. The mean CD4/CD8 ratio before and after treatment was 2.00 \pm 1.05 and $1.80 \pm 0.83$, respectively $(\mathrm{p}<0.06)$. The abnormally high CD4/CD8 ratio before treatment declined after 1 week of cyanocobalamin administration.

The absolute number and the CD3 (\%) and CD7 (\%) cells were elevated with treatment. However, the increment was statistically significant for $\mathrm{CD} 3$ cells but not for CD7 (table 2, fig. 1).

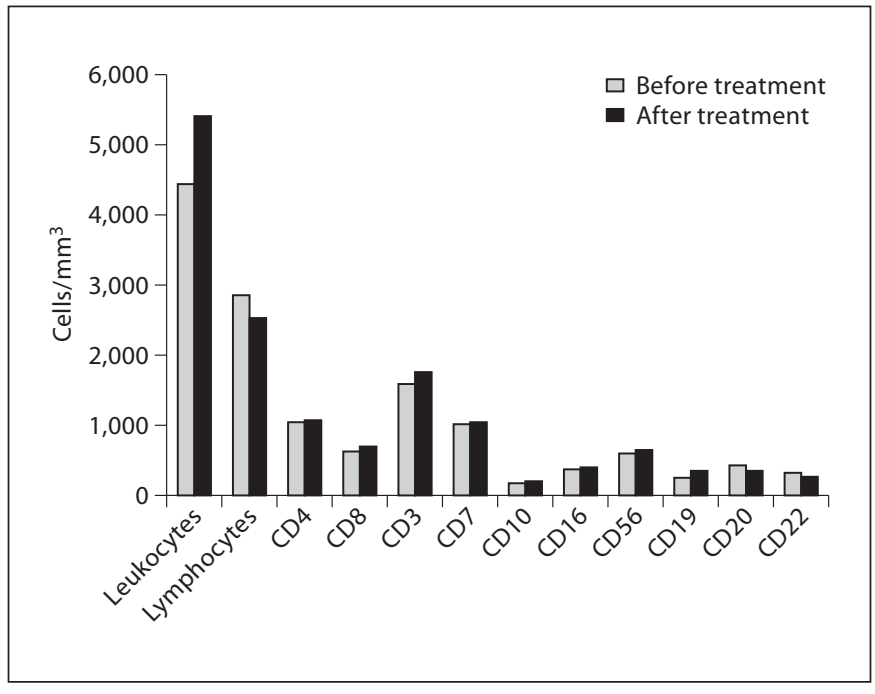

Fig. 1. Changes in immune parameters by cyanocobalamin treatment. 
Effects of Cyanocobalamin on B Lymphocyte Subsets

The absolute number and CD10 (\%) were slightly elevated with treatment. However, the increment was not statistically significant. The absolute number and CD19 (\%) were significantly elevated when compared with pretreatment values. The absolute number and CD20 (\%) declined after treatment, but only the former was statistically significant. CD22 (\%) declined too, but not significantly. The absolute numbers of B lymphocyte subsets before and after cyanocobalamin treatment are shown in table 2 and figure 1.

\section{Effects of Cyanocobalamin Administration on NK}

Lymphocyte Subsets, Serum Immunoglobulin and

Complement Levels

Both absolute number and CD16 (\%) and CD56 (\%) were found to be elevated after treatment although the increase was not significant. These changes are also listed in table 2 and figure 1.

Serum levels of immunoglobulins and complement before and after treatment are given in table 2 . While a significant elevation was observed in C3 level after treatment, C4 level showed only a slight elevation (table 2). When compared with pretreatment values, IgG, IgA and IgM levels were elevated after treatment. Increment in immunoglobulin levels with treatment was statistically significant (table 2).

\section{Discussion}

Vitamin $B_{12}$ deficiency results in megaloblastic anemia, peripheral nervous system disorder, and in animal models, depression of immune defense against viruses and bacteria [8]. It has been reported that vitamin $B_{12}$ treatment restores the immune parameters in patients with megaloblastic anemia [1-5].

Concanavalin A-dependent $\mathrm{T}$ cell proliferation and pokeweed mitogen-dependent immunoglobulin synthesis in B cells were also shown to be increased by vitamin $B_{12}$ [7]. In contrast to these observations, Soler et al. [9] and Carmel et al. [10] reported that in patients with pernicious anemia there was no increase in $\mathrm{CD} 4+/ \mathrm{CD} 8+$ ratio or a significant decrease in CD8+ absolute number. Cyanocobalamin has been reported to restore both abnormal CD4+/CD8+ ratio, and decrease in absolute number of CD8+, but no change in absolute number of CD4+ cells was observed [6]. We observed that cyanocobalamin administration had restored the decrease in absolute number of $\mathrm{CD} 8+$ cells which was the main abnormality, but no significant increase in absolute number of CD4+ cells was seen.

Absolute numbers of CD3 and CD19 significantly increased after cyanocobalamin administration, but CD10 and CD7 were slightly elevated. The levels of serum IgG, IgA, and IgM were significantly elevated. These observations are consistent with the proposition that vitamin $\mathrm{B}_{12}$ favors humoral and cellular immunity. Lymphocyte apoptosis can be prevented by vitamin $\mathrm{B}_{12}$ administration and may thus improve immunologic abnormalities observed in pernicious anemia. Previous studies suggested that ineffective hematopoiesis caused by vitamin $B_{12}$ deficiency concerned primarily CD8+ cells $[11,12]$. In our patients with pernicious anemia, decline in absolute numbers of lymphocytes and CD8+ cells was partially restored by vitamin $B_{12}$ administration. However, the role of CD8+ in this regard warrants further studies.

The cyanocobalamin-mediated recovery from depressed NK cell function in our vitamin $B_{12}$ patients are in accordance with another study where lymphocyte and NK cell functions were completely restored and serum levels of vitamin $B_{12}$ returned to normal after 1 year of vitamin $B_{12}$ treatment [6]. Hsing et al. [13] reported that increase in absolute numbers of CD3-, CD16+, and CD57+ cells (these cells have strong NK cell activity) after vitamin $B_{12}$ treatment had augmented the antitumor activity.

Two studies reported that serum C3, IgG, and IgM levels declined in vitamin $\mathrm{B}_{12}$-deficient rats and this decline was restored after vitamin $B_{12}$ administration [14, 15]. Our patients also showed a significant increase in serum levels of C3, IgG, IgA, and IgM, and a slight elevation in $\mathrm{C} 4$ level after vitamin $\mathrm{B}_{12}$ treatment. These effects of vitamin $B_{12}$ may be responsible for the decrease observed in the incidence of infections in vitamin $\mathrm{B}_{12}$-deficient patients after treatment.

\section{Conclusion}

The replacement of vitamin $B_{12}$ in patients with pernicious anemia restored, at least in the early phase of treatment, the significant decrease in the number of CD8+ cells and the depression of NK cell activity and serum immunoglobulin levels. Assessment after a prolonged treatment or recovery from anemia might have shown a more substantial improvement of the immunological parameters. These observations may contribute to our understanding of some of the potential protective effects of vitamin $\mathrm{B}_{12}$. 


\section{References}

-1 Imamura N, Fujimura K, Kuramoto A: Lymphocyte subpopulations in pernicious anemia. N Engl J Med 1984;311:56.

$\checkmark 2$ Wodzinski MA, Forrest MJ, Barnett D: Lymphocyte subpopulations in patients with hydroxocobalamin responsive megaloblastic anemia. J Clin Pathol 1985;38:582-584

3 Gogos CA, Kapatais-Zoumbos KN, Zoumbos NC: Lymphocyte sub-populations in megaloblastic anaemia due to vitamin $B_{12}$ deficiency. Scand J Haematol 1986;37:316318.

-4 Kubota K, Arai T, Tamura J: Restoration of decreased suppresser cells by vitamin $\mathrm{B}_{12}$ therapy in a patient with pernicious anemia. Am J Hematol 1987;24:221-223.

$\checkmark 5$ Kubota K, Kurabayashi H, Kawada E, Okamoto K, Shirakura T: Restoration of abnormally high CD4/CD8 ratio and low natural killer cell activity by vitamin $B_{12}$ therapy in a patient with post-gastrectomy megaloblastic anemia. Intern Med 1992;31:125-126.
-6 Tamura J, Kubota K, Murakami H, et al: Immunomodulation by vitamin $\mathrm{B}_{12}$ : augmentation of CD8+ $\mathrm{T}$ lymphocytes and natural killer $(\mathrm{NK})$ cell activity in vitamin $\mathrm{B}_{12}$-deficient patients by methyl- $\mathrm{B}_{12}$ treatment. Clin Exp Immunol 1999;116:28-34.

7 Sakane T, Takeda S, Kotani H: Effect of methyl $B_{12}$ on the in vitro immune functions of human T Iymphocytes. J Clin Immunol 1982;2:101-109.

8 Vellema P, Rutten VP, Hoek A, Moll L, Wentink GH: The effect of cobalt supplementation on the immune response in vitamin $\mathrm{B}_{12}$ deficient Texel lambs. Vet Immunol Immunopathol 1996;55:151-161.

-9 Soler J, Remacha A, Nieto M, Gimferrer E: Lymphocyte subpopulations in patients with untreated pernicious anemia. Scand J Haematol 1985;35:377.

10 Carmel R, Boone D, Parker JW: Lymphocyte surface phenotypes in pernicious anemia. Dig Dis Sci 1987;32:846-850.
11 Bunting RW, Seling MK, Dickersin GR: Apoptotic cells in peripheral blood from patients with low serum cobalamin. J Submicrosc Cytol Pathol 1997;29:223-227.

12 Ingram CF, Davidoff AN, Marais E: Evaluation of DNA analysis for evidence of apoptosis in megaloblastic anaemia. Br J Haematol 1997;96:576-583.

13 Hsing AW, Hansson LE, McLaughlin JK: Pernicious anemia and subsequent cancer: a population-based cohort study. Cancer 1993; 71:745-750.

14 Wada M, Kawata T, Yamada K, Funada U, Kuwamori M, Endo M, Tanaka N, Tadokoro T, Maekawa A: Serum C3 content in vitamin $\mathrm{B}_{12}$-deficient rats. Int J Vitam Nutr Res 1998; 68:94-97.

15 Funada U, Wada M, Kawata T, Mori K, Tamai H, Kawanishi T, Kunou A, Tanaka N, Tadokoro T, Maekawa A: Changes in CD4+CD8-/CD4-CD8+ ratio and humoral immune functions in vitamin $\mathrm{B}_{12}$-deficient rats. Int J Vitam Nutr Res 2000;70:167-171. 